\title{
A novel halo-alkali-tolerant and thermo-tolerant chitinase from Pseudoalteromonas sp. DC14 isolated from the Caspian Sea
}

\author{
A. Makhdoumi ${ }^{1} \cdot$ Z. Dehghani-Joybari $^{1} \cdot$ M. Mashreghi ${ }^{1} \cdot$ K. Jamialahmadi $^{2,3}$. \\ A. Asoodeh ${ }^{4}$
}

Received: 16 November 2014/Revised: 21 April 2015/Accepted: 5 July 2015/Published online: 22 July 2015

(C) Islamic Azad University (IAU) 2015

\begin{abstract}
A novel halo-alkali and thermo-tolerant chitinase was obtained from an isolated strain found in the Caspian Sea. The effects of media composition and various fermentation conditions for the optimization of chitinase production were studied one factor at a time and by response surface methodology. The novel strain, which is designated as strain DC14 and phylogenetically related to the genus Pseudoalteromonas, produced chitinase after $72 \mathrm{~h}$ under the following optimal conditions: glucose $1 \%$ (w/v), ammonium sulphate $0.2 \%(\mathrm{w} / \mathrm{v})$, chitin $1.07 \%(\mathrm{w} /$ v), $\mathrm{pH} 8, \mathrm{NaCl} 10 \%(\mathrm{w} / \mathrm{v})$, inoculums size $2.5 \%(\mathrm{v} / \mathrm{v})$, temperature $30{ }^{\circ} \mathrm{C}, \mathrm{CaCl}_{2} 3 \mathrm{mM}$ and $\mathrm{MgCl}_{2} 4 \mathrm{mM}$. Using the statistical optimization method, chitinase production was found to increase from 2.30 to $21.90 \mathrm{U} / \mathrm{dl}$. The enzyme showed maximum activity at $40{ }^{\circ} \mathrm{C}, \mathrm{pH} 9$ and $10 \% \mathrm{NaCl}$. It was stable in a wide range of temperature from 15 to $65{ }^{\circ} \mathrm{C}, \mathrm{pH}$ from $\mathrm{pH} 7$ to 11 and $\mathrm{NaCl}$ concentration from 0 to $15 \%(\mathrm{w} / \mathrm{v})$. The molecular weight of the enzyme was estimated by SDS-PAGE to be about $65 \mathrm{kDa}$. With regard to the halo-alkali and thermo-stable properties of this enzyme, it has potential industrial activity.
\end{abstract}

A. Makhdoumi

a.makhdomi@um.ac.ir

1 Department of Biology, Faculty of Science, Ferdowsi University of Mashhad, Mashhad, P.O. Box: 91775-1436, Iran

2 Biotechnology Research Center, Mashhad University of Medical Sciences, Mashhad, Iran

3 Department of Medical Biotechnology, School of Medicine, Mashhad University of Medical Sciences, Mashhad, Iran

4 Department of Chemistry, Faculty of Science, Ferdowsi University of Mashhad, Mashhad, Iran
Keywords Chitinase Pseudoalteromonas . Extremozyme $\cdot$ Caspian Sea

\section{Introduction}

Chitin, a poly- $\beta(1,4)$ linear-linked $N$-acetylglucosamine (GlcNAc), is the second most abundant biopolymer on earth after cellulose (Khoushab and Yamabhai 2010). Chitin polymers are mostly present in the exoskeleton components of arthropods and in the cell walls of fungi (Herring 1979; Souza et al. 2011). Chitinases (E.C. 3.2.1.14) are a group of enzymes capable of hydrolysing insoluble chitin to its oligo (chitosan and chitobiose) and monomeric ( $N$-acetylglucosamine) components (Bhattacharya et al. 2007). Chitinases occur in a wide range of organisms including viruses, bacteria, fungi, insects, higher plants and animals for offensive, defensive, morphogenetic or nutritional purposes (Park et al. 1997; Dahiya et al. 2006).

Although chitin can be obtained as a cheap renewable biopolymer, especially from marine sources, the chitinase hydrolytic products are an expensive and valuable natural material for a wide variety of biotechnological and industrial applications (Dahiya et al. 2006; Chen et al. 2010). Moreover, chitinases have attracted interest as biocontrol agents due to their ability to degrade chitin in the fungal cell wall and insect exoskeleton (Tsujibo et al. 2003; Mostafa et al. 2009). It has been estimated that the annual production of chitin in aquatic systems is roughly equal to $10^{10}-10^{11}$ metric tons (Beier and Bertilsson 2013). In spite of the continuous production of chitin in the marine ecosystems, there is a low level of chitin accumulation in these environments (Alldredge and Gotschalk 1990). Chitinolytic bacteria, which are very abundant and widely distributed in marine environments, are responsible for 
rapid degradation of chitin in aqueous systems (Keyhani and Roseman 1996). Accordingly, there are numerous reports about the isolation of bacterial chitinase from marine environments (Tsujibo et al. 1998; Itoi et al. 2007; Stefanidi and Vorgias 2008). Because most industrial processes are carried out in harsh physicochemical conditions, which may not be definitively adjusted to the optimal conditions required for the activity of the available enzymes, it would be of great value to have enzymes that demonstrate optimal activities in wide ranges of salinity, temperature and $\mathrm{pH}$ values.

In this paper, we describe the characteristics of a haloalkali and thermo-tolerant chitinase obtained from Pseudoalteromonas sp. DC14 isolated in the Caspian Sea and its production optimization.

\section{Materials and methods}

\section{Microorganism isolation and identification}

Sampling was carried out at $30 \mathrm{~m}$ depth in a southern region of the Caspian Sea $\left(36.46^{\circ} \mathrm{N} 51.02^{\circ} \mathrm{E}\right)$. A solid media was applied for the isolation procedure, which contained $(\mathrm{g} / \mathrm{l})$ : $\left(\mathrm{NH}_{4}\right)_{2} \mathrm{SO}_{4}, 0.86 ; \mathrm{MgSO}_{4} \cdot 7 \mathrm{H}_{2} \mathrm{O}, 0.75 ; \mathrm{FeSO}_{4} \cdot 7 \mathrm{H}_{2} \mathrm{O}, 0.009$; $\mathrm{CaCl}_{2} \cdot 2 \mathrm{H}_{2} \mathrm{O}, 0.22 ; \mathrm{MgCl}_{2} \cdot 6 \mathrm{H}_{2} \mathrm{O}, 0.17 ; \mathrm{KCl}, 0.13 ; \mathrm{NaCl}, 9.1$; peptone, 10 ; yeast extract, 5 ; glucose, 2 ; and agar, 15 . The $\mathrm{pH}$ of the medium was adjusted to 8.2 with $2 \mathrm{M} \mathrm{NaOH}$. Inoculated plates were incubated at $20{ }^{\circ} \mathrm{C}$ for 2 months. After successive cultivation, a pure isolate was obtained. The bacterial isolate was maintained on the slant above-mentioned solid media at $4{ }^{\circ} \mathrm{C}$ and broth media supplemented with $30 \%(\mathrm{v} / \mathrm{v})$ glycerol at $-80{ }^{\circ} \mathrm{C}$ for short and long preservation, respectively. The genomic DNA of the strain was extracted by DNA extraction kit (Thermo Scientific, Lithuania) according to the manufacturer's recommended procedure, and the 16S rRNA gene was amplified using the bacterial universal primers $27 \mathrm{~F}$ and $1492 \mathrm{R}$ (Lane et al. 1985). The sequencing was conducted on an ABI 3730XL DNA sequencer at Macrogen (Seoul, South Korea). Phylogenetic analysis was performed using the software package MEGA version 6 (Tamura et al. 2013).

\section{Preparation of colloidal chitin and primary screening}

Colloidal chitin was prepared from purified chitin (Merck) by the modified method of Roberts and Selitrennikoff (1988). Briefly, $5 \mathrm{~g}$ of chitin powder was slowly added to $90 \mathrm{ml}$ of concentrated $\mathrm{HCl}$ under vigorous stirring for $2 \mathrm{~h}$. The mixture was added to $500 \mathrm{ml}$ of ice-cold $95 \%$ ethanol under vigorous stirring for $30 \mathrm{~min}$ and kept overnight at $25^{\circ} \mathrm{C}$. The precipitation was collected by centrifugation and washed with $0.1 \mathrm{M}$ sodium phosphate buffer $(\mathrm{pH} 7)$ until the $\mathrm{pH}$ of the colloidal chitin became neutral. Qualitative chitinase assay was performed by spot inoculation of the bacterial strain on the solid isolation media containing $1.5 \%$ (w/v) colloidal chitin. The chitinase activity was indicated by the clear zone around colonies after incubation for 2 weeks at $20{ }^{\circ} \mathrm{C}$.

\section{Measurement of chitinase production}

Chitinase production was assayed with colloidal chitin as a substrate. The culture medium contained $(\mathrm{g} / \mathrm{l}):\left(\mathrm{NH}_{4}\right)_{2} \mathrm{SO}_{4}$, $0.86 ; \mathrm{MgSO}_{4} \cdot 7 \mathrm{H}_{2} \mathrm{O}, 0.75 ; \mathrm{FeSO}_{4} \cdot 7 \mathrm{H}_{2} \mathrm{O}, 0.009 ; \mathrm{CaCl}_{2} \cdot 2 \mathrm{H}_{2}$ $\mathrm{O}, 0.22 ; \mathrm{MgCl}_{2} \cdot 6 \mathrm{H}_{2} \mathrm{O}, 0.17 ; \mathrm{KCl}, 0.13 ; \mathrm{NaCl}, 9.1$; yeast extract, 2 ; and colloidal chitin, $1.5 \%$ (v/v). The $\mathrm{pH}$ was 8.2. The fermentation process was conducted in a 50-ml Erlenmeyer flask at $20{ }^{\circ} \mathrm{C}$ and $150 \mathrm{rpm}$ for $72 \mathrm{~h}$. The cultures were centrifuged at $10,000 \times g$ for $15 \mathrm{~min}$ at $4{ }^{\circ} \mathrm{C}$, and the supernatant (crude enzyme solution) was used for chitinase assay. Enzyme solution $(0.3 \mathrm{ml})$ was added to $0.3 \mathrm{ml}$ of substrate solution, which contained a $0.5 \%$ suspension of colloidal chitin in $100 \mathrm{mM}$ sodium phosphate buffer $(\mathrm{pH}$ 8.0). The mixture was incubated at $30{ }^{\circ} \mathrm{C}$ for $45 \mathrm{~min}$. After centrifugation, the amount of reducing sugar produced in the supernatant was determined by Schales' method (Imoto and Yagishita 1971) and the dinitrosalicylic acid (DNS) method (Reissig et al. 1955) with $N$-acetylglucosamine as a reference compound. One unit of chitinase activity was defined as the amount of enzyme that produced $1 \mu \mathrm{mol}$ of reducing sugars per minute.

\section{Experimental design for enzyme optimization}

To understand the effects of various conditions on the amount of chitinase production and identify the most important factors, a conventional 'one-factor-at-a-time' approach was applied. For this method, in each experiment we vary only one factor, while keeping others fixed. Various concentrations of $\mathrm{NaCl}(0-15 \% \mathrm{w} / \mathrm{v})$; different carbon sources $(1 \% \mathrm{w} / \mathrm{v})$ : glucose, fructose, maltose, saccharose and starch; different nitrogen sources $(0.2 \% \mathrm{w} /$ v): peptone, yeast extract, casein, urea and ammonium sulphate; chitin substrate $(0-5 \% \mathrm{w} / \mathrm{v})$; various concentrations of $\mathrm{pH}(6.0-10.0)$, inoculum size $(0.5-4.5 \% \mathrm{v} / \mathrm{v})$, temperature $\left(15-35^{\circ} \mathrm{C}\right)$; and metal ions $(0-4 \mathrm{mM})$ of calcium, magnesium, zinc, manganese and copper were chosen as the critical variables. To evaluate the combinatorial effects of variables and optimum condition for the chitinase production, Box-Behnken response surface methodology (RSM) was applied. Optimization studies were carried out by studying the effect of four major variables including $\mathrm{NaCl}$, chitin, $\mathrm{pH}$ and temperature at three levels. The behaviour of the system is explained by the following empirical second-order polynomial model: 
Table 1 Coded and actual values for Box-Behnken design

\begin{tabular}{lcll}
\hline Independent variables & \multicolumn{4}{l}{ Range and level } \\
\cline { 2 - 4 } & -1 & 0 & 1 \\
\hline $\mathrm{NaCl}\left(\% \mathrm{w} / \mathrm{v}, X_{1}\right)$ & 3 & 6.5 & 10 \\
$\mathrm{Chitin}\left(\% \mathrm{w} / \mathrm{v}, X_{2}\right)$ & 0 & 0.75 & 1.5 \\
$\mathrm{pH}\left(X_{3}\right)$ & 6 & 7 & 8 \\
$T\left({ }^{\circ} \mathrm{C}, X_{4}\right)$ & 20 & 25 & 30 \\
\hline
\end{tabular}

$$
\begin{aligned}
Y= & \beta_{0}+\beta_{1} X_{1}+\beta_{2} X_{2}+\beta_{3} X_{3}+\beta_{4} X_{4}+\beta_{11} X_{12}^{2}+\beta_{22} X_{22}^{2} \\
& +\beta_{33} X_{32}^{2}+\beta_{44} X_{42}^{2}+\beta_{12} X_{1} X_{2}+\beta_{13} X_{1} X_{3}+\beta_{14} X_{1} X_{4} \\
& +\beta_{23} X_{2} X_{3}+\beta_{24} X_{2} X_{4}+\beta_{34} X_{3} X_{4} .
\end{aligned}
$$

where $Y$ is the predicted enzyme activity; $x_{i}, x_{j}, \ldots, x_{k}$ are the input variables, which affect the response $Y$; $x_{i}^{2}, x_{j}^{2}, \ldots, x_{k}^{2}$ are the square effects; $x_{i} x_{j}, x_{i} x_{k}$ and $x_{j} x_{k}$ are the interaction effects; $\beta_{0}$ is the intercept term; $\beta_{i}(i=1,2$, $\ldots, k)$ is the linear effect; $\beta_{i i}(i=1,2, \ldots, \mathrm{k})$ is the squared effect and $\beta_{i j}(i=1,2, \ldots, k ; j=1,2, \ldots, k)$ is the interaction effect. Coded levels for independent variables are presented in Table 1.

\section{Characterization of partially purified chitinase}

Optimized culture supernatants (crude enzyme) were spun in a centrifuge at $12,000 \times g$ for $20 \mathrm{~min}\left(4^{\circ} \mathrm{C}\right)$ and then collected for ammonium sulphate precipitation $(70 \%$, w/v). The precipitates were formed, kept overnight and collected by centrifugation at $12,000 \times g$ for $20 \mathrm{~min}\left(4^{\circ} \mathrm{C}\right)$. They were then dissolved in a small amount of $50 \mathrm{mM}$ Tris buffer $(\mathrm{pH}$ 8.0) and dialysed against the same buffer. Concentration of protein was estimated based on Bradford's method using bovine serum albumin (BSA) as standard protein.

\section{Effects of salinity on enzyme activity and stability}

The optimum $\mathrm{NaCl}$ concentration for chitinase activity was determined by incubation of the partially purified enzymes with the substrates at the saline buffer that ranged from 0 to $20 \% \mathrm{NaCl}$, under standard assay conditions. Salt stability was measured by pre-incubation of the enzymes without substrates in sodium phosphate buffer $(50 \mathrm{mM}, \mathrm{pH} 8.0)$ supplemented with $0-20 \% \mathrm{NaCl}$ at $4{ }^{\circ} \mathrm{C}$ temperature for $30 \mathrm{~min}$. Then, the remaining activity was measured under standard conditions.

\section{Effects of temperature on enzyme activity and stability}

The optimum temperature for chitinase activity was examined by incubation of the partially purified enzymes with the substrates at temperatures that ranged from 20 to $60{ }^{\circ} \mathrm{C}$ under standard assay conditions. Thermal stability was determined by pre-incubation of the enzymes without substrates in sodium phosphate buffer ( $\mathrm{pH} \mathrm{8.0)}$ for $30 \mathrm{~min}$ at temperatures from 20 to $60{ }^{\circ} \mathrm{C}$. The remaining activity was measured under standard conditions.

\section{Effects of pH on enzyme activity and stability}

The optimum $\mathrm{pH}$ of chitinase was investigated by the varied $\mathrm{pH}$ of the reaction buffers, ranging from 6.0 to 10.0 ; $50 \mathrm{mM}$ of each buffer was used: acetate $(\mathrm{pH} 4.0-6.0)$, potassium phosphate $(\mathrm{pH} 7.0-8.0)$ and glycine- $\mathrm{NaOH}(\mathrm{pH}$ $9.0-10.0$ ). The enzymes were pre-incubated at various $\mathrm{pH}$ buffers that used the above systems at $4{ }^{\circ} \mathrm{C}$ for $30 \mathrm{~min}$ without substrates and then subjected to enzyme assays under standard conditions to determine the $\mathrm{pH}$ stability. All experiments were repeated at least three times.

\section{SDS-polyacrylamide gel electrophoresis}

SDS-PAGE analysis of proteins is carried out using $12.5 \%$ (w/v) polyacrylamide gel at $120 \mathrm{~V}$ for $90 \mathrm{~min}$. Solutions for preparing $12.5 \%(\mathrm{w} / \mathrm{v})$ resolving gel included $\mathrm{H}_{2} \mathrm{O}$ $(6.4 \mathrm{ml}), 30 \%$ acrylamide mix $(8.3 \mathrm{ml}), 1.5 \mathrm{M}$ Tris $(\mathrm{pH}$ $8.8,5 \mathrm{ml}), 10 \%(\mathrm{w} / \mathrm{v})$ SDS $(0.2 \mathrm{ml}), 10 \%(\mathrm{w} / \mathrm{v})$ ammonium persulphate $(0.1 \mathrm{ml})$ and $N, N, N, N^{\prime}$-tetramethylethylenediamine (0.008 ml) (Laemmli 1970).

\section{Results and discussion}

Marine environments encompass about $70 \%$ of the earth's surface, with countless marine microorganisms containing biochemical secrets which might provide new insights into and understanding of enzymes (Das et al. 2006). Marine bacteria have been attracting more attention as a resource for new bioactive compounds recently, as the soil-derived compounds have yielded high numbers of the previously described metabolites (Toledo et al. 2006; Bhatnagar and Kim 2010; Trincone 2011). The present study was conducted to optimize a marine bacterium chitinase production and examine its properties.

\section{Taxonomic characteristics of chitinase-producing strain}

Strain DC14 was isolated from $30 \mathrm{~m}$ depth in the southern region of the Caspian Sea. The isolated strain was a gramstain-negative, catalase- and oxidase-positive, non-motile rod-shaped bacterium. The clear zone was observed around the colonies on the chitin-containing solid media, which qualitatively indicated its chitinolytic activity (Fig. 1). The 


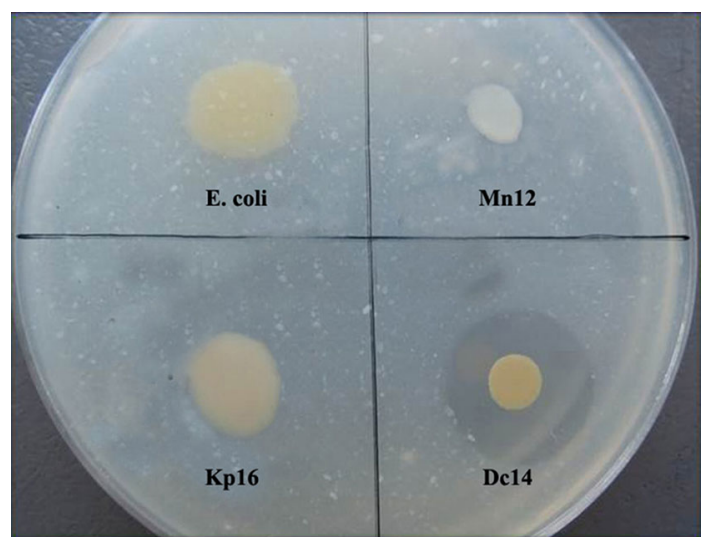

Fig. 1 Assay of chitinolytic activity on plate with solid isolation medium supplemented with colloidal chitin $[1.5 \%$ (w/v)]. Clearing zone of chitin utilization formed around the colony of strain DC12 but not around E. coli and two non-chitinolytic isolated strains: KP16 and MN12

16S rRNA gene sequence analysis revealed that strain DC14 is a member of the genus Pseudoalteromonas. The closest relatives of strain DC14 were Pseudoalteromonas lipolytica $\mathrm{LMEB}^{\mathrm{T}}{ }^{\mathrm{T}}$, Pseudoalteromonas donghaensis $\mathrm{HJ}_{51}{ }^{\mathrm{T}}$ and Pseudoalteromonas shioyasakiensis $\mathrm{SE} 3^{\mathrm{T}}$, with a 16S rRNA gene sequence similarity of $99.1,98.4$ and $97.4 \%$, respectively. Phylogenetic analysis using the neighbour-joining algorithm supports the view that the novel strain is a member of this genus (Fig. 2). Several bacterial strains from various genera of both soil and marine ecosystems were reported to contain chitinolytic activity. Bacterial strains from Aeromonas (Sashiwa et al. 2002), Alteromonas (Tsujibo et al. 1993; Orikoshi et al. 2005), Arthrobacter (Lonhienne et al. 2001; Wang et al.
2009), Bacillus (Alam et al. 1995; Sampson and Gooday 1998; Yuli et al. 2004), Entrobacter (Chernin et al. 1995), Flavobacterium (Campbell and Williams 1951), Microbulbifer (Howard et al. 2003), Micrococcus (Campbell and Williams 1951), Moritella (Stefanidi and Vorgias 2008), Nocardia (Bansode and Bajekal 2006), Pseudomonas (Wang and Chang 1997), Salinivibrio (Aunpad and Panbangred 2003), Serratia (Horn et al. 2006), Streptomyces (Tsujibo et al. 1993; Tsujibo et al. 2000; Tsujibo et al. 2003), Vibrio (Fukasawa et al. 1992; Osama and Koga 1995) and Virgibacillus (Essghaier 2012) were noted for their chitinolytic activity. Recently, Wang and co-workers reported the isolation of chitinase-producing Pseudoalteromonas. That enzyme showed its maximum activity at pH 8 and $20{ }^{\circ} \mathrm{C}$ (Wang et al. 2014).

\section{Optimization of chitinase production by the one- factor-at-a-time approach}

In order to identify the most relevant factors to chitinase production with Pseudoalteromonas sp. DC14, the onefactor-at-a-time method was conducted as described above. The effects of various factors/levels are presented in Table 2. It showed that the key parameters were $\mathrm{NaCl}$ $(10 \% \mathrm{w} / \mathrm{v})$, glucose $(1 \% \mathrm{w} / \mathrm{v}),\left(\mathrm{NH}_{4}\right)_{2} \mathrm{SO}_{4}(0.2 \% \mathrm{w} / \mathrm{v})$, chitin $(0.5 \% \mathrm{v} / \mathrm{v}), \mathrm{pH} 7$, inoculums size $(2.5 \% \mathrm{v} / \mathrm{v})$, temperature $30{ }^{\circ} \mathrm{C}, \mathrm{CaCl}_{2} 3 \mathrm{mM}, \mathrm{MgCl}_{2} 3 \mathrm{mM}$. This resulted in the production of $8.50 \mathrm{U} / \mathrm{dl}$ chitinase after $72 \mathrm{~h}$. Minimum amounts of $\mathrm{ZnCl}_{2}, \mathrm{MnCl}_{2}$ and $\mathrm{CuCl}_{2}$ completely inhibited the enzyme production. The experimental results clearly showed that the $\mathrm{NaCl}$ concentration, nitrogen source, inoculums' size and temperature are the most

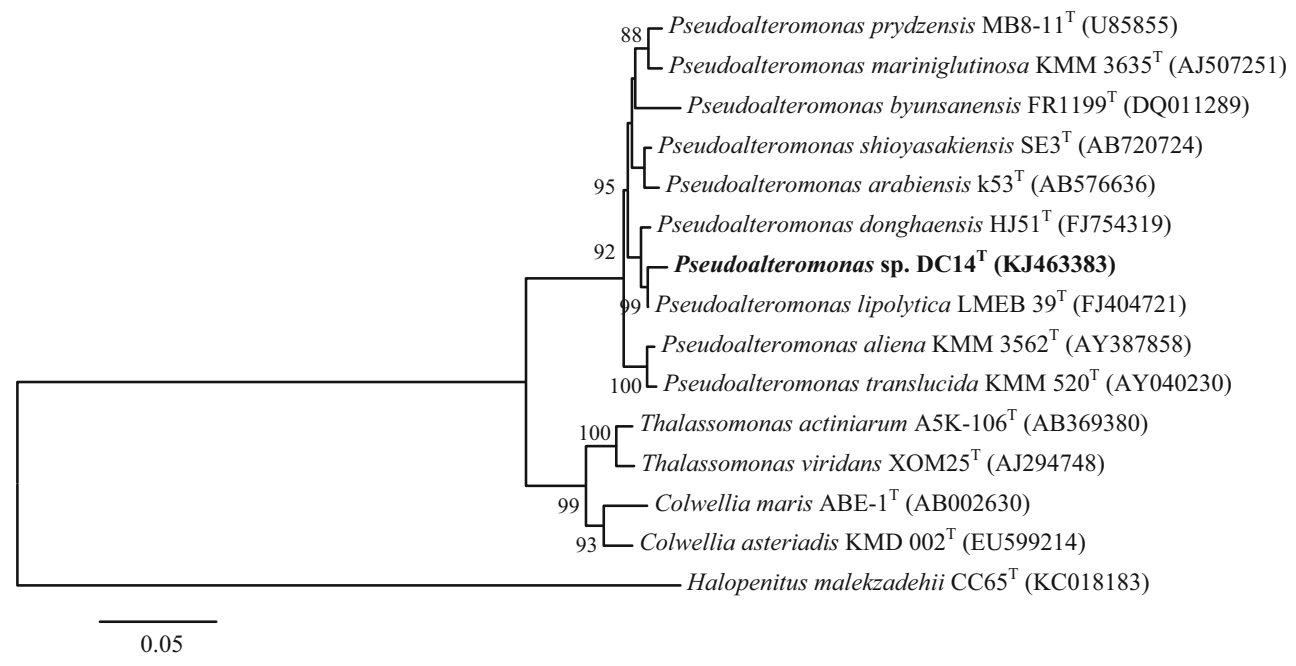

Fig. 2 Neighbour-joining phylogenetic tree based on 16S rRNA gene sequences showing the relationship of strain $\mathrm{DC} 14^{\mathrm{T}}$ with other members of the genus Pseudoalteromonas. Accession numbers of the sequences are given in parentheses. The sequences of the Halopenitus malekzadehii $\mathrm{CC}^{\mathrm{T}}{ }^{\mathrm{T}}$ (KC018183) was used as an outgroup. Bootstrap values (\%) are based on 1000 replicates. Bar 0.05 substitutions per nucleotide position 
Table 2 The design and results of OFAT for chitinase production (optimum levels presented in bold)

\begin{tabular}{|c|c|c|c|c|c|}
\hline \multirow{2}{*}{$\frac{\text { Runs }}{\mathrm{NaCl}}$} & \multicolumn{5}{|c|}{ Various levels/chitinase activity U/dl (in parentheses) } \\
\hline & 0 & 3 & 7 & 10 & 15 \\
\hline$(\% \mathrm{w} / \mathrm{v})$ & $(0)$ & $(0.5 \pm 0.01)$ & $(0.7 \pm 0.04)$ & $(2.70 \pm 0.2)$ & $(1.10 \pm 0.1)$ \\
\hline Carbon sources $(1 \%$ w/v) & $\begin{array}{l}\text { Glucose } \\
(3.50 \pm 0.1)\end{array}$ & $\begin{array}{l}\text { Fructose } \\
(3.00 \pm 0.3)\end{array}$ & $\begin{array}{l}\text { Maltose } \\
(3.30 \pm 0.7)\end{array}$ & $\begin{array}{l}\text { Saccharose } \\
(3.10 \pm 0.3)\end{array}$ & $\begin{array}{l}\text { Starch } \\
(3.00 \pm 0.3)\end{array}$ \\
\hline Nitrogen sources $(0.2 \% \mathrm{w} / \mathrm{v})$ & $\begin{array}{l}\text { Peptone } \\
(3.20 \pm 0.2)\end{array}$ & $\begin{array}{l}\text { Yeast extract } \\
(2.90 \pm 0.4)\end{array}$ & $\begin{array}{l}\text { Casein } \\
(2.80 \pm 0.3)\end{array}$ & $\begin{array}{l}\text { Urea } \\
(3.20 \pm 0.6)\end{array}$ & $\begin{array}{l}\left(\mathrm{NH}_{4}\right)_{2} \mathrm{SO}_{4} \\
(5.50 \pm 0.6)\end{array}$ \\
\hline $\begin{array}{l}\text { Chitin } \\
(\% \mathrm{v} / \mathrm{v})\end{array}$ & $\begin{array}{l}0 \\
(4.20 \pm 0.5)\end{array}$ & $\begin{array}{l}0.5 \\
(5.80 \pm 0.5)\end{array}$ & $\begin{array}{l}1.5 \\
(5.00 \pm 0.3)\end{array}$ & $\begin{array}{l}3 \\
(3.70 \pm 0.4)\end{array}$ & $\begin{array}{l}5 \\
(3.70 \pm 0.3)\end{array}$ \\
\hline $\mathrm{pH}$ & $\begin{array}{l}6 \\
(4.70 \pm 0.4)\end{array}$ & $\begin{array}{l}7 \\
(6.00 \pm 0.2)\end{array}$ & $\begin{array}{l}8 \\
(5.50 \pm 0.3)\end{array}$ & $\begin{array}{l}9 \\
(5.30 \pm 0.4)\end{array}$ & $\begin{array}{l}10 \\
(4.50 \pm 0.5)\end{array}$ \\
\hline $\begin{array}{l}\text { Inoculum size } \\
(\% \mathrm{v} / \mathrm{v})\end{array}$ & $\begin{array}{l}0.5 \\
(0.90 \pm 0.02)\end{array}$ & $\begin{array}{l}1.5 \\
(4.00 \pm 0.4)\end{array}$ & $\begin{array}{l}2.5 \\
(6.10 \pm 0.3)\end{array}$ & $\begin{array}{l}3.5 \\
(5.00 \pm 0.3)\end{array}$ & $\begin{array}{l}4.5 \\
(4.50 \pm 0.4)\end{array}$ \\
\hline Temperature $\left({ }^{\circ} \mathrm{C}\right)$ & $\begin{array}{l}15 \\
(1.00 \pm 0.09)\end{array}$ & $\begin{array}{l}20 \\
(6.00 \pm 0.4)\end{array}$ & $\begin{array}{l}25 \\
(6.60 \pm 0.2)\end{array}$ & $\begin{array}{l}30 \\
(7.20 \pm 0.3)\end{array}$ & $\begin{array}{l}37 \\
(2.60 \pm 0.5)\end{array}$ \\
\hline \multicolumn{6}{|l|}{ Metal ions (mM) } \\
\hline $\mathrm{Ca}^{2+}$ & $\begin{array}{l}0 \\
(0.0)\end{array}$ & $\begin{array}{l}1 \\
(6.90 \pm 0.7)\end{array}$ & $\begin{array}{l}2 \\
(7.20 \pm 0.6)\end{array}$ & $\begin{array}{l}3 \\
(8.00 \pm 0.3)\end{array}$ & $\begin{array}{l}4 \\
(7.60 \pm 0.3)\end{array}$ \\
\hline $\mathrm{Mg}^{2+}$ & $\begin{array}{l}0 \\
(0.30 \pm 0.01)\end{array}$ & $\begin{array}{l}1 \\
(6.20 \pm 0.6)\end{array}$ & $\begin{array}{l}2 \\
(7.00 \pm 0.5)\end{array}$ & $\begin{array}{l}3 \\
(8.40 \pm 0.4)\end{array}$ & $\begin{array}{l}4 \\
(7.30 \pm 0.3)\end{array}$ \\
\hline $\mathrm{Zn}^{2+}$ & $\begin{array}{l}0 \\
(8.30 \pm 0.4)\end{array}$ & $\begin{array}{l}1 \\
(4.00 \pm 0.6)\end{array}$ & $\begin{array}{l}2 \\
(3.60 \pm 0.3)\end{array}$ & $\begin{array}{l}3 \\
(1.50 \pm 0.3)\end{array}$ & $\begin{array}{l}4 \\
(0.0)\end{array}$ \\
\hline $\mathrm{Mn}^{2+}$ & $\begin{array}{l}0 \\
(8.40 \pm 0.2)\end{array}$ & $\begin{array}{l}1 \\
(0.0)\end{array}$ & $\begin{array}{l}2 \\
(0.0)\end{array}$ & $\begin{array}{l}3 \\
(0.0)\end{array}$ & $\begin{array}{l}4 \\
(0.0)\end{array}$ \\
\hline $\mathrm{Cu}^{2+}$ & $\begin{array}{l}0 \\
(8.50 \pm 0.3)\end{array}$ & $\begin{array}{l}1 \\
(0.0)\end{array}$ & $\begin{array}{l}2 \\
(0.0)\end{array}$ & $\begin{array}{l}3 \\
(0.0)\end{array}$ & $\begin{array}{l}4 \\
(0.0)\end{array}$ \\
\hline
\end{tabular}

effective parameters in chitinase production, with 27,27 , 52 and $62 \%$ variations between their levels, respectively. This optimization enhanced the enzyme production more than 3.1 times. However, the OFAT approach has the limitation of ignoring the importance of the interaction of various physiological parameters. The statistical approach using response surface methodology for process optimization serves this purpose by finding out the optimal condition in any given system by a set of independent variables over a specific region of interest through establishing the relationship between more than one variable. It has proven to be a powerful tool in optimizing the fermentation condition (Box and Behnken 1960; Han et al. 2008)

\section{Response surface methodology optimization}

The four significant variables selected based on the results of OFAT design ( $\mathrm{NaCl}$, chitin, $\mathrm{pH}$ and temperature) were optimized using Box-Behnken response surface methodology. Experimental design and the actual yields of chitinase (response) obtained in the experiments are given in Table 3. The highest chitinase activity of $20.0 \mathrm{U} / \mathrm{dl}$ was obtained at the following condition after $72 \mathrm{~h}$ (run 4): $\mathrm{NaCl}$ $6.5(\% \mathrm{w} / \mathrm{v})$, chitin $(0.75 \% \mathrm{w} / \mathrm{v}), \mathrm{pH} 8$ and temperature $20{ }^{\circ} \mathrm{C}$. Based on the analysis of the results, the predicted optimized culture condition was at $\mathrm{NaCl}(10 \% \mathrm{w} / \mathrm{v})$, chitin $(1.07 \% \mathrm{w} / \mathrm{v}), \mathrm{pH} 8$ and temperature $20^{\circ} \mathrm{C}$. It was predicted to produce chitinase at $23.0 \mathrm{U} / \mathrm{dl}$. The model was validated for the four variables within the optimized condition. The experiment resulted in $22.1 \mathrm{U} / \mathrm{dl}$ chitinase production, which was 2.6 times better than that observed with the one-at-a-time method. The ANOVA results of RSM optimization are given in Table 4 . The $P$ value serves as a tool for checking the significance of each of the coefficients and is indicative of the interaction strength of each independent variable. Four interaction coefficients, including $\mathrm{AC}(\mathrm{NaCl} / \mathrm{pH}), \mathrm{AD}(\mathrm{NaCl} / \mathrm{Temperature}), \mathrm{BD}$ (chitin/temperature) and $\mathrm{CD}$ ( $\mathrm{pH} /$ temperature), are significant, as evidenced by low $\mathrm{P}$ and high $\mathrm{F}$ values. The response surfaces from the interactions are illustrated in Fig. 3. $R^{2}$ value for this model is 0.9795 , which indicates that the variability in the observed response can be explained by the experimental parameters and their interactions. The fermentation process at the optimal conditions predicted by this approach resulted in an 8.2 times 
Table 3 Experimental design matrix and results of Box-Behnken

\begin{tabular}{|c|c|c|c|c|c|}
\hline \multirow[t]{2}{*}{ Run } & \multicolumn{5}{|l|}{ Variables } \\
\hline & $\begin{array}{l}\mathrm{NaCl} \\
(\% \mathrm{w} / \mathrm{v})\end{array}$ & $\begin{array}{l}\text { Chitin } \\
(\% \mathrm{w} / \mathrm{v})\end{array}$ & $\mathrm{pH}$ & $\begin{array}{l}\text { Temperature } \\
\left({ }^{\circ} \mathrm{C}\right)\end{array}$ & $\begin{array}{l}\text { Chitinase } \\
\text { activity (U/dl) }\end{array}$ \\
\hline 1 & 6.5 & 0 & 8 & 25 & $4.20 \pm 0.3$ \\
\hline 2 & 3 & 0 & 7 & 25 & $0.00 \pm 0.0$ \\
\hline 3 & 3 & 0.75 & 6 & 25 & $2.00 \pm 0.07$ \\
\hline 4 & 6.5 & 0.75 & 8 & 20 & $20.00 \pm 0.9$ \\
\hline 5 & 3 & 1.5 & 7 & 25 & $0.00 \pm 0.0$ \\
\hline 6 & 6.5 & 1.5 & 6 & 25 & $6.80 \pm 0.4$ \\
\hline 7 & 6.5 & 1.5 & 7 & 30 & $0.00 \pm 0.0$ \\
\hline 8 & 6.5 & 0 & 6 & 25 & $0.00 \pm 0.0$ \\
\hline 9 & 10 & 0.75 & 7 & 30 & $6.50 \pm 0.2$ \\
\hline 10 & 10 & 0.75 & 8 & 25 & $15.00 \pm 0.9$ \\
\hline 11 & 6.5 & 0 & 7 & 30 & $5.80 \pm 0.6$ \\
\hline 12 & 3 & 0.75 & 7 & 30 & $7.60 \pm 0.4$ \\
\hline 13 & 6.5 & 1.5 & 7 & 20 & $9.10 \pm 0.5$ \\
\hline 14 & 10 & 0.75 & 7 & 20 & $12.80 \pm 0.8$ \\
\hline 15 & 6.5 & 0.75 & 6 & 30 & $11.20 \pm 0.3$ \\
\hline 16 & 10 & 1.5 & 7 & 25 & $7.70 \pm 0.3$ \\
\hline 17 & 6.5 & 0.75 & 6 & 20 & $3.60 \pm 0.1$ \\
\hline 18 & 6.5 & 0 & 7 & 20 & $0.00 \pm 0.0$ \\
\hline 19 & 3 & 0.75 & 7 & 20 & $0.00 \pm 0.0$ \\
\hline 20 & 10 & 0.75 & 6 & 25 & $5.30 \pm 0.2$ \\
\hline 21 & 10 & 0 & 7 & 25 & $2.00 \pm 0.1$ \\
\hline 22 & 6.5 & 0.75 & 8 & 30 & $7.50 \pm 0.3$ \\
\hline 23 & 6.5 & 0.75 & 7 & 25 & $13.60 \pm 0.5$ \\
\hline 24 & 6.5 & 0.75 & 7 & 25 & $13.80 \pm 0.3$ \\
\hline 25 & 6.5 & 0.75 & 7 & 25 & $13.80 \pm 0.4$ \\
\hline 26 & 3 & 0.75 & 8 & 25 & $4.30 \pm 0.1$ \\
\hline 27 & 6.5 & 1.5 & 6 & 25 & $0.00 \pm 0.0$ \\
\hline
\end{tabular}

Bold values indicate optimum experiment

enhancement of the preliminary enzyme production. In this study, the chitinase production reached $22.1 \mathrm{U} / \mathrm{dl}$ in a 50 -ml shake flask after incubating for $72 \mathrm{~h}$ (end of exponential growth phase) in the optimum fermentation medium (Fig. 4). The results for the reported chitinase production varied between 0.1 and more than $60 \mathrm{U} / \mathrm{ml}$ (Bhushan 2000; Vaidya et al. 2001; Singh et al. 2009; Souza et al. 2009). These variations were observed because of the strains and the level of enzyme purification. Our chitinase production is relatively low, and the application of recombinant DNA technology will be helpful to increase its production.

\section{Effects of $\mathrm{NaCl}, \mathrm{pH}$ and temperature on enzyme stability and activity}

The effects of salinity, $\mathrm{pH}$ and temperature on the stability and activity of the chitinase from the marine-isolated strain
Table 4 Analysis of variance for response surface quadratic model

\begin{tabular}{|c|c|c|c|c|c|}
\hline Source & $\begin{array}{l}\text { Sum of } \\
\text { square }\end{array}$ & $\begin{array}{l}\text { Degree of } \\
\text { freedom }\end{array}$ & $\begin{array}{l}\text { Mean } \\
\text { square }\end{array}$ & $F$ & $P$ \\
\hline Model & 0.081 & 14 & 0.0058 & 30.46 & $<0.05$ \\
\hline $\mathrm{A}-\mathrm{NaCl}$ & 0.0104 & 1 & 0.0104 & 54.76 & $<0.05$ \\
\hline B-chitin & 0.0011 & 1 & 0.0011 & 5.88 & 0.031 \\
\hline C-pH & 0.0106 & 1 & 0.0106 & 55.69 & $<0.05$ \\
\hline D-temperature & 0.0003 & 1 & 0.0003 & 2.08 & 0.137 \\
\hline $\mathrm{AB}$ & 0.0008 & 1 & 0.0008 & 4.26 & 0.06 \\
\hline $\mathrm{AC}$ & 0.0013 & 1 & 0.0013 & 7.18 & $<0.05$ \\
\hline $\mathrm{AD}$ & 0.0048 & 1 & 0.0048 & 25.33 & $<0.05$ \\
\hline $\mathrm{BC}$ & 0.0001 & 1 & 0.0001 & 0.89 & 0.362 \\
\hline BD & 0.0055 & 1 & 0.0055 & 29.10 & $<0.05$ \\
\hline $\mathrm{CD}$ & 0.0101 & 1 & 0.0101 & 52.96 & $<0.05$ \\
\hline $\mathrm{A}^{2}$ & 0.0026 & 1 & 0.0102 & 53.94 & $<0.05$ \\
\hline $\mathrm{B}^{2}$ & 0.0297 & 1 & 0.0327 & 171.96 & $<0.05$ \\
\hline $\mathrm{C}^{2}$ & 0.0017 & 1 & 0.0028 & 14.85 & $<0.05$ \\
\hline $\mathrm{D}^{2}$ & 0.0016 & 1 & 0.0016 & 8.85 & 0.010 \\
\hline Residual & 0.0022 & 12 & 0.00019 & & \\
\hline Lack-of-fit & 0.0022 & 10 & 0.00022 & 15.77 & 0.061 \\
\hline Pure error & 0.000029 & 2 & 0.000014 & & \\
\hline Total & 0.083 & 26 & & & \\
\hline
\end{tabular}

Pseudoalteromonas sp. DC14 are shown in Fig. 5. The optimum $\mathrm{NaCl}$ concentration was $10 \%(\mathrm{w} / \mathrm{v})$, while the enzyme was stable in a wide range of salt concentration from 0 to $15 \%(\mathrm{w} / \mathrm{v})$. The maximum $\mathrm{pH}$ activity of the obtained chitinase was at $\mathrm{pH} 9$, and it could be considered an alkali-stable enzyme which was stable at an alkaline $\mathrm{pH}$ between $\mathrm{pH} 8$ and 11. The enzyme maintained more than $60 \%$ of its activity in a broad range of temperature from 20 to $60{ }^{\circ} \mathrm{C}$ and showed its highest activity at $40{ }^{\circ} \mathrm{C}$. In spite of the relatively low-level production, the enzyme showed very interesting properties. It was stable in a wide range of salinity, from 0 to $15 \%(\mathrm{w} / \mathrm{v}), \mathrm{pH}$ from $\mathrm{pH} 7$ to 11 and temperature from 15 to $65^{\circ} \mathrm{C}$. There are some reports about halo (Essghaier et al. 2012), alkali (Sorokin et al. 2012) and thermo-tolerant (Bhushan 2000; Christodoulou et al. 2001; Dai et al. 2011) chitinase, but the poly-extremophilic features of the novel enzyme made it a good candidate for industrial applications. The halo-tolerant nature of the enzyme is important because most industrial waste has a high level of salinity. Furthermore, halo-tolerant chitinase may be applied as biocontrol agent to control disease in salt-tolerant plants (Essghaier et al. 2012). Chitinase with alkaline $\mathrm{pH}$ stability has major potential in insect biological control, as their chitinous gut environments have an alkaline $\mathrm{pH}$ condition (Bansode and Bajekal 2006). Alkaline chitinase also has benefits in the management of alkaline chitinous waste from some 

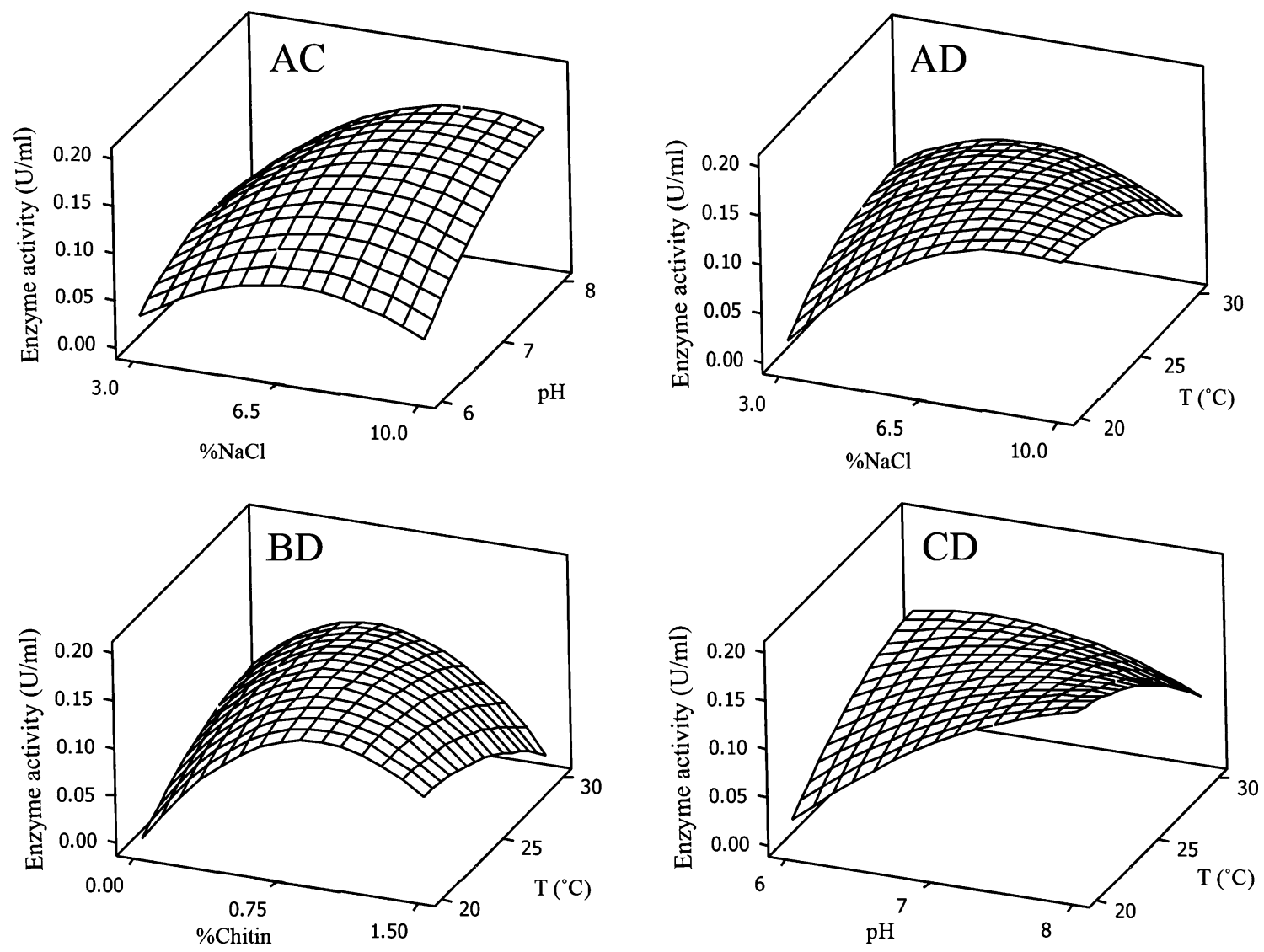

Fig. 3 Response surface plot of chitinase production by Pseudoalteromonas sp. DC14 showing the interactions between the $\mathrm{NaCl}$ and $\mathrm{pH}(A C)$, $\mathrm{NaCl}(\% \mathrm{w} / \mathrm{v})$ and temperature $\left({ }^{\circ} \mathrm{C}\right)(A D)$, chitin $(\% \mathrm{w} / \mathrm{v})$ and temperature $\left({ }^{\circ} \mathrm{C}\right)(B D), \mathrm{pH}$ and temperature $\left({ }^{\circ} \mathrm{C}\right)(\mathrm{CD})$

Fig. 4 Enzyme production (solid line) and bacterial growth (dashed line) in the optimal cultivation conditions

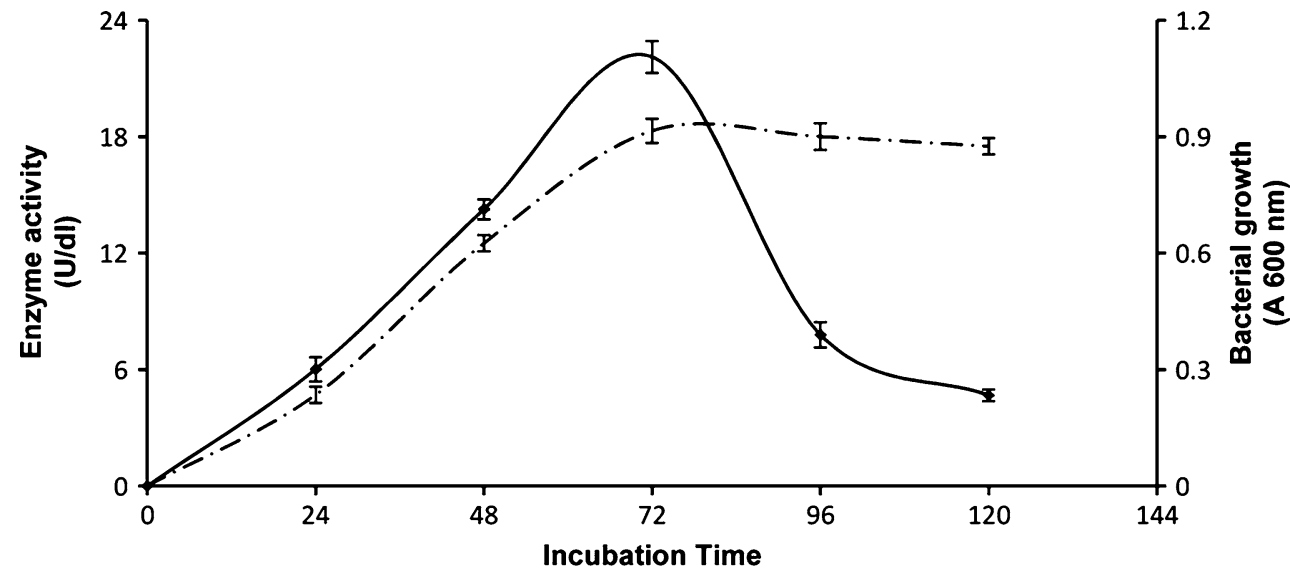

(h) industries, like the food industry (Nawani and Kapadnis 2003). The isolated strain could produce chitinase at temperatures between 20 and $30{ }^{\circ} \mathrm{C}$. The low producing temperature reduces the energy consumption in industry, and also the novel isolate may be applicable in field conditions against fungi and insect plant pathogens.

\section{Molecular weight of chitinase}

By the use of ammonium sulphate precipitation (70\% saturation), protein fraction was separated from theoretically optimized culture medium. Based on our process, specific activity in the culture medium was increased from 

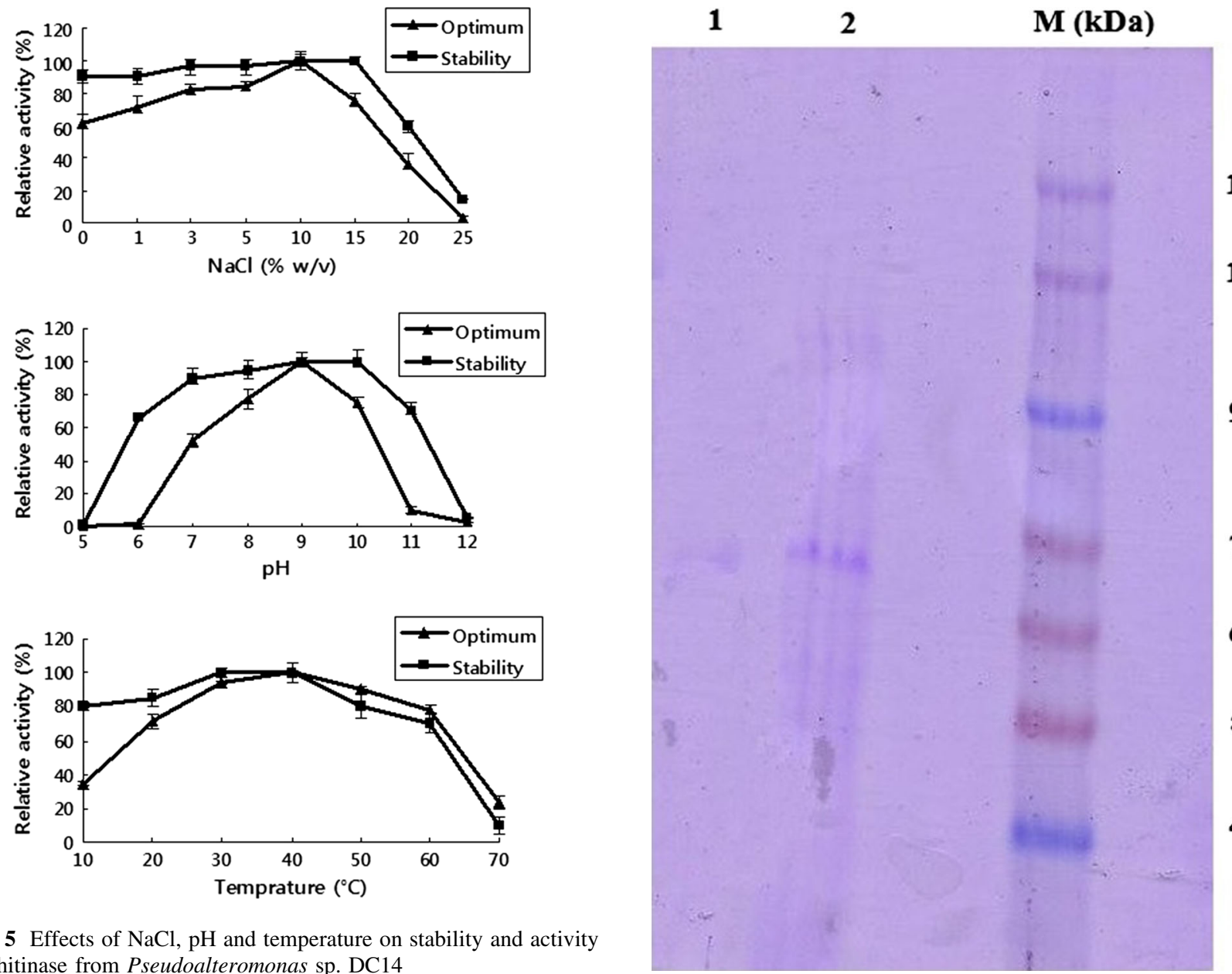

Fig. 5 Effects of $\mathrm{NaCl}, \mathrm{pH}$ and temperature on stability and activity of chitinase from Pseudoalteromonas sp. DC14

Table 5 Partial purification of chitinase from Pseudoalteromonas sp. DC14

\begin{tabular}{lllll}
\hline Purification step & $\begin{array}{l}\text { Specific } \\
\text { activity } \\
(\mathrm{U} / \mathrm{mg})\end{array}$ & $\begin{array}{l}\text { Total } \\
\text { protein } \\
(\mathrm{mg})\end{array}$ & $\begin{array}{l}\text { Total } \\
\text { activity } \\
(\mathrm{U})\end{array}$ & $\begin{array}{l}\text { Purification } \\
\text { (fold) }\end{array}$ \\
\hline Culture medium & 2.2 & 275.0 & 602.2 & 1.00 \\
$\begin{array}{l}\text { Ammonium sulphate } \\
\text { precipitation }\end{array}$ & 5.6 & 8.5 & 43.3 & 2.54 \\
\hline
\end{tabular}

2.19 to $5.57 \mathrm{U} / \mathrm{ml}$ in precipitation stage. Our results also showed 2.54-fold purification (Table 5). The SDS-PAGE analysis of the purified enzyme revealed one protein band with an estimated molecular weight of $65 \mathrm{kDa}$ (Fig. 6).

\section{Conclusion}

We elucidated the isolation of chitinolytic bacteria from the Caspian Sea for the first time. The results of phylogenetic analysis based on the 16S rRNA gene sequence analysis and phenotypic characterization showed that the

Fig. 6 SDS-PAGE of chitinase. Lane 1 supernatant of culture medium, Lane 2 ammonium sulphate precipitated protein; Lane $M$ molecular weight markers

novel isolate belongs to the genus Pseudoalteromonas. The overall results show that this bacterium has great potential capability to produce $\mathrm{N}$-acetylglucosamine in a wide range of reaction conditions. The GlcNAc and its analogues could be used to produce biofuel and also valuable pharmacological compounds for the treatment of a wide variety of ailments. The novel strain could furthermore be applied as a biocontrol agent against fungi and insect plant pathogens.

Acknowledgments This work was supported by a grant from Ferdowsi University of Mashhad (27244/3).

\section{References}

Alam MM, Nikaidou N, Tanaka H, Watanabe T (1995) Cloning and sequencing of chic gene of Bacillus circulans WL-12 and relationship of its product to some other chitinases and chitinase like proteins. J Ferment Bioeng 80:454-461 
Alldredge AL, Gotschalk CC (1990) The relative contribution of marine snow of different origins to biological processes in coastal waters. Cont Shelf Res 10:41-58

Aunpad R, Panbangred W (2003) Cloning and characterization of the constitutively expressed chitinase $\mathrm{C}$ gene from a marine bacterium, Salinivibrio costicola strain 5SM-1. J Biosci Bioeng 96:529-536

Bansode VB, Bajekal SS (2006) Characterization of chitinases from microorganisms isolated from Lonar lake. Indian J Biotechnol $5: 357-363$

Beier S, Bertilsson S (2013) Bacterial chitin degradation-mechanisms and ecophysiological strategies. Front Microbiol 4:1-12

Bhatnagar I, Kim SK (2010) Immense essence of excellence: marine microbial bioactive compounds. Mar Drugs 8(10):2673-2701

Bhattacharya D, Nagpure A, Gupta RK (2007) Bacterial chitinases: properties and potential. Crit Rev Biotechnol 27:21-28

Bhushan B (2000) Production and characterization of a thermostable chitinase from a new alkalophilic Bacillus sp. BG-11. J Appl Microbiol 88:800-808

Box GEP, Behnken DW (1960) Some new three level designs for the study of quantitative variables. Technometrics 2:455-475

Campbell LL, Williams OB (1951) A study of chitin-decomposing micro-organisms of marine origin. J Gen Microbiol 5:894-905

Chen JK, Shen CR, Liu CL (2010) $N$-Acetylglucosamine: production and applications. Mar Drugs 8:2493-2516

Chernin L, Ismailov Z, Haran S, Chet I (1995) Chitinolytic Enterobacter agglomerans antagonistic to fungal plant pathogens. Appl Environ Microbiol 61:1720-1726

Christodoulou E, Duffner F, Vorgias CE (2001) Overexpression, purification, and characterization of a thermostable chitinase (Chi40) from Streptomyces thermoviolaceus OPC-520. Protein Expr Purif 23:97-105

Dahiya N, Tewari R, Hoondal GS (2006) Biotechnological aspects of chitinolytic enzymes: a review. Appl Microbiol Biotechnol 71:773-782

Dai DH, Hu WL, Huang GR, Li W (2011) Purification and characterization of a novel extracellular chitinase from thermophilic Bacillus sp. HU1. Afr J Biotechnol 10:2476-2485

Das S, Lyla PS, Khan SA (2006) Marine microbial diversity and ecology: importance and future perspectives. Curr Sci 90:1325-1335

Essghaier B, Hedi A, Bejji M, Jijakli H, Boudabous A, Sadfi-Zouaoui N (2012) Characterization of a novel chitinase from a moderately halophilic bacterium, Virgibacillus marismortui strain M323. Ann Microbiol 62:835-841

Fukasawa S, Arai M, Wada T, Shima H, Kurata M (1992) Some properties of a chitinase from a marine luminous bacterium, Vibrio fischeri strain COT-A136. Chem Pharm Bull 40:1631-1633

Han Y, Li Z, Miao X, Zhang F (2008) Statistical optimization of medium components to improve the chitinase activity of Streptomyces sp. Da11 associated with the South China Sea sponge Craniella australiensis. Process Biochem 43:1088-1093

Herring PJ (1979) Marine ecology and natural products. Pure Appl Chem 51:1901-1911

Horn SJ, Sørbotten A, Synstad B, Sikorski P, Sørlie M, Varum KM, Eijsink VG (2006) Endo/exo mechanism and processivity of family 18 chitinases produced by Serratia marcescens. FEBS J 273:491-503

Howard M, Ekborg N, Taylor L, Weiner R, Hutcheson S (2003) Genomic analysis and initial characterization of the chitinolytic system of Microbulbifer degradans strain 2-40. J Bacteriol 185:3352-3360

Imoto T, Yagishita K (1971) A simple activity measurement of lysozyme. Agric Biol Chem 35:1154-1156
Itoi S, Kanomata Y, Koyama Y, Kadokura K, Uchida S, Nishio T, Oku T, Sugita H (2007) Identification of a novel endochitinase from a marine bacterium Vibrio proteolyticus strain No. 442. Biochim Biophys Acta 1774:1099-1107

Keyhani NO, Roseman S (1996) The chitin catabolic cascade in the marine bacterium Vibrio furnissii. Molecular cloning, isolation, and characterization of a periplasmic chitodextrinase. J Biol Chem 271:33414-33424

Khoushab F, Yamabhai M (2010) Chitin research revisited. Mar Drugs 8:1988-2012

Laemmli UK (1970) Cleavage of structural proteins during the assembly of the head of bacteriophage T4. Nature 277:680-685

Lane DJ, Pace B, Olsen GJ, Stahl D, Sogin M, Pace NR (1985) Rapid determination of $16 \mathrm{~S}$ ribosomal RNA sequences for phylogenetic analyses. Proc Natl Acad Sci 82:6955-6959

Lonhienne T, Mavromatis K, Vorgias CE, Buchon L, Gerday C, Bouriotis V (2001) Cloning, sequences, and characterization of two chitinase genes from the Antarctic Arthrobacter sp. strain TAD20: isolation and partial characterization of the enzymes. J Bacteriol 183:1773-1779

Mostafa SA, Mahmoud MS, Mohamed ZK, Enan MR (2009) Cloning and molecular characterization of chitinase from Bacillus licheniformis MS-3. J Gen Appl Microbiol 55:241-246

Nawani NN, Kapadnis BP (2003) Chitin degrading potential of bacteria from extreme and moderate environment. Indian J Exp Biol 41:248-254

Orikoshi H, Nakayama S, Miyamoto K, Hanato C, Yasuda M, Inamori Y, Tsujibo H (2005) Roles of four chitinases (ChiA, $\mathrm{ChiB}$, ChiC, and ChiD) in the chitin degradation system of marine bacterium Alteromonas sp. strain O-7. Appl Environ Microb 71:1811-1815

Osama R, Koga T (1995) An investigation of aquatic bacteria capable of utilizing chitin as the sole source of nutrients. Lett Appl Microbiol 21:288-291

Park JK, Morita K, Fukumoto I, Yamasaki Y, Nakagawa T, Kawamukai M, Matsuda H (1997) Purification and characterization of the Chitinase (ChiA) from Enterobacter sp. G-1. Biosci Biotechnol Biochem 61:684-689

Reissig JL, Strominger JL, Leloir LF (1955) A modified colorimetric method for the estimation of $\mathrm{N}$-acetylamino sugars. J Biol Chem 217:959-966

Roberts WK, Selitrennikoff CP (1988) Plant and bacterial chitinases differ in antifungal activity. J Gen Microbiol 134:169-176

Sampson MN, Gooday GW (1998) Involvement of chitinases of Bacillus thuringiensis during pathogenesis in insects. Microbiol 144:2189-2194

Sashiwa H, Fujishima S, Yamano N, Kawasaki N, Nakayama A, Muraki E, Hiraga K, Oda K, Aiba S (2002) Purification of $\mathrm{N}$-acetyl D-glucosamine from alpha-chitin by crude enzymes from Aeromonas hydrophila H-2330. Carbohydr Res 337:761-763

Singh AK, Mehta G, Chhatpar HS (2009) Optimization of medium constituents for improved chitinase production by Paenibacillus sp. D1 using statistical approach. Lett Appl Microbiol 49:708-714

Sorokin DY, Tourova TP, Sukhacheva MV, Mardanov AV, Ravin NV (2012) Bacterial chitin utilisation at extremely haloalkaline conditions. Extremophiles 16:883-894

Souza CP, Burbano-Rosero EM, Almeida BC, Martins GG, Albertini LS, Rivera IN (2009) Culture medium for isolating chitinolytic bacteria from seawater and plankton. World $\mathrm{J}$ Microbiol Biotechnol 25:2079-2082

Souza CP, Almeida BC, Colwell RR, Rivera IN (2011) The importance of chitin in the marine environment. Mar Biotechnol 13:823-830 
Stefanidi E, Vorgias CE (2008) Molecular analysis of the gene encoding a new chitinase from the marine psychrophilic bacterium Moritella marina and biochemical characterization of the recombinant enzyme. Extremophiles 12:541-552

Tamura K, Stecher G, Peterson D, Filipski A, Kumar S (2013) MEGA6: molecular evolutionary genetics analysis version 6.0. Mol Biol Evol 30:2725-2729

Toledo G, Green W, Gonzalez RA, Christoffersen L, Podar M, Chang HW, Hemscheidt T, Trapido-Rosenthal HG, Short JM, Bidigare RR, Mathur EJ (2006) High throughput cultivation for isolation of novel marine microorganisms. Oceanography 19:120-125

Trincone A (2011) Marine biocatalysts: enzymatic features and applications. Mar Drugs 9:478-499

Tsujibo H, Minoura K, Miyamoto K, Endo H, Moriwaki M, Inamori Y (1993a) Purification and properties of a thermostable chitinase from Streptomyces thermoviolaceus OPC-520. Appl Environ Microbiol 59:620-622

Tsujibo H, Orikoshi H, Tanno H, Fujimoto K, Miyamoto K, Imada C, Okami Y, Inamori Y (1993b) Cloning, sequence, and expression of a chitinase gene from a marine bacterium Alteromonas sp. Strain O-7. J Bacteriol 175:176-181

Tsujibo H, Orikoshi H, Shiotani D, Hayashi M, Umeda J, Miyamoto K, Imada C, Okami Y, Inamori Y (1998) Characterization of chitinase $\mathrm{C}$ from a marine bacterium, Altermonas sp. strain O-7, and its corresponding gene and domain structure. Appl Environ Microbiol 64:472-478

Tsujibo H, Hatano N, Endo H, Miyamoto K, Inamori Y (2000) Purification and characterization of a thermostable chitinase from Streptomyces thermoviolaceus OPC-520 and cloning of the encoding gene. Biosci Biotechnol Biochem 64:96-102

Tsujibo H, Kubota T, Yamamoto M, Miyamoto K, Inamori Y (2003) Characterization of chitinase genes from an alkaliphilic actinomycete, Nocardiopsis prasina OPC-131. Appl Environ Microbiol 69:894-900

Vaidya RJ, Shah IM, Vyas PR, Chhatpar HS (2001) Production of chitinase and its optimization from a novel isolate Alcaligenes xylosoxydans: potential in antifungal biocontrol. World $\mathrm{J}$ Microbiol Biotechnol 17:691-696

Wang SL, Chang WT (1997) Purification and characterization of two bifunctional chitinases/lysozymes extracellularly produced by Pseudomonas aeruginosa K-187 in shrimp and crab shell powder medium. Appl Environ Microbiol 63:380-386

Wang F, Gai Y, Chen M, Xiao X (2009) Arthrobacter psychrochitiniphilus sp. nov., a psychrotrophic bacterium isolated from Antarctica. Int J Syst Evol Microbiol 59:2759-2762

Wang X, Zhao Y, Tan H, Chi N, Zhang Q, Du Y, Yin H (2014) Characterisation of a chitinase from Pseudoalteromonas sp. DL6 , a marine psychrophilic bacterium. Int $\mathrm{J}$ Biol Macromol $70: 455-462$

Yuli PE, Suhartono MT, Rukayadi Y, Hwang JK, Pyun YR (2004) Characteristics of thermostable chitinase enzymes from the Indonesian Bacillus sp. 13.26. Enzyme Microb Technol 35:147-153 